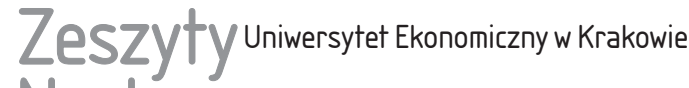 Naukowe
}

Viktor Shevchuk

Roman Kopych

Mariana Holynska

\section{Efekty makroekonomiczne polityki fiskalnej i monetarnej w gospodarkach Europy Środkowej i Wschodniej}

\section{Streszczenie}

Cel: Celem artykułu jest zbadanie wpływu bilansu budżetowego oraz podaży pieniądza na inflację cen produkcyjnych (PPI), bilans obrotów bieżących oraz lukę dochodu dla wybranych pięciu krajów Europy Środkowej i Wschodniej (EŚSW), tj. Bułgarii, Czech, Węgier, Polski i Rumunii.

Metodyka badań: Do modelowania efektów makroekonomicznych bilansu budżetowego i podaży pieniądza dla próby danych kwartalnych z lat 2000-2017 wykorzystano struk-

Viktor Shevchuk, Politechnika Krakowska im. Tadeusza Kościuszki, Instytut Ekonomii, Socjologii i Filozofii, ul. Warszawska 24, 31-155 Kraków, e-mail: vshevchuk@pk.edu.pl, ORCID: https:// orcid.org/0000-0002-7125-1267.

Roman Kopych, Lviv National University named by Ivan Franko, Department of International Economic Relations, Universytetska 1, 79000 Lviv, Ukraine, e-mail: kopych_r@bigmir.net, ORCID: https://orcid.org//0000-0002-3986-7694.

Mariana Holynska, Lviv University of Trade and Economics, Department of Law, Tuhan-Baranovskoho 5, 79005 Lviv, Ukraine, e-mail: marianna.yasinska@ukr.net, ORCID: https:// orcid.org//0000-0002-5865-5910.

Artykuł udostępniany na licencji Creative Commons Uznanie autorstwa-Użycie niekomercyjne-Bez utworów zależnych 4.0 (CC BY-NC-ND 4.0); https://creativecommons.org/licenses/ by-nc-nd/4.0/ 
turalny model autoregresyjny (SVAR), który przewiduje uzależnienie podaży pieniądza w bieżącym okresie od bilansu obrotów bieżących, przy jednoczesnej zależności tego wskaźnika równowagi zewnętrznej od cyklu koniunkturalnego.

Wyniki badań: Ustalono, że we wszystkich pięciu krajach EŚW poprawa bilansu budżetowego nie wywołuje niekorzystnych zmian dochodu. W większości krajów (Bułgaria, Czechy, Polska) nadwyżka budżetowa prowadzi do spowolnienia inflacji cen produkcyjnych, a także poprawy bilansu obrotów bieżących (Czechy, Polska, Węgry). Nadwyżka budżetowa powoduje przeważnie zwiększenie podaży pieniądza. Poluzowanie polityki monetarnej prowadzi zarówno do pogorszenia bilansu budżetowego (Bułgaria, Polska), jak i do krótkookresowej poprawy tego wskaźnika (Czechy, Węgry). Efekty makroekonomiczne wywołane zmianą podaży pieniądza są bardziej zróżnicowane, co przemawia na korzyść efektów monetarnych tak po stronie popytowej, jak i podażowej.

Wnioski: Otrzymane rezultaty wskazują na to, że większe korzyści wynikają z prowadzenia konserwatywnej polityki fiskalnej i monetarnej we wszystkich badanych krajach EŚSW, a przede wszystkim w Polsce i Czechach.

Wkład w rozwój dyscypliny: Przeprowadzone badania uzasadniają wykorzystanie modelu gospodarki zależnej z dwoma sektorami - dóbr będących i niebędących przedmiotem wymiany w handlu międzynarodowym (tradable and nontradable goods) - do analizy polityki ekonomicznej prowadzonej w krajach EŚSW.

Słowa kluczowe: bilans budżetowy, podaż pieniądza, bilans obrotów bieżących, cykl koniunkturalny, inflacja cen produkcyjnych.

Klasyfikacja JEL: C5, E5, H6.

\section{Wprowadzenie}

Trwająca obecnie dyskusja na temat wad i zalet polityki fiskalnych oszczędności (fiscal austerity) oraz potencjalnych korzyści prowadzenia autonomicznej polityki pieniężnej pobudza zainteresowanie efektami makroekonomicznymi zwiększenia nadwyżki budżetowej i podaży pieniądza. Warto zaznaczyć, że w ostatnich latach widoczna jest tendencja do poprawy bilansu budżetowego w każdym z pięciu analizowanych w artykule krajów Europy Środkowej i Wschodniej (EŚSW), tj. w Bułgarii, Czechach, Polsce, Rumunii i na Węgrzech (rys. 1a). Jednocześnie występuje zwiększenie podaży pieniądza (rys. 1b), słabsze jednak niż obserwowane w kontekście deficytu budżetowego z lat 2006-2008 (wyjątkiem jest Bułgaria). Wydaje się, że cechą wspólną wybranych krajów EŚW jest poprawa bilansu obrotów bieżących (rys. 1d) oraz malejąca inflacja cen produkcyjnych (rys. 1c). Cykle koniunkturalne krajów EŚW - oprócz Węgier, które w latach 2006-2007 doświadczyły wcześniejszej destabilizacji makroekonomicznej z powodu kryzysu zadłużenia - wyglądają bardzo podobnie (rys. 1e). 


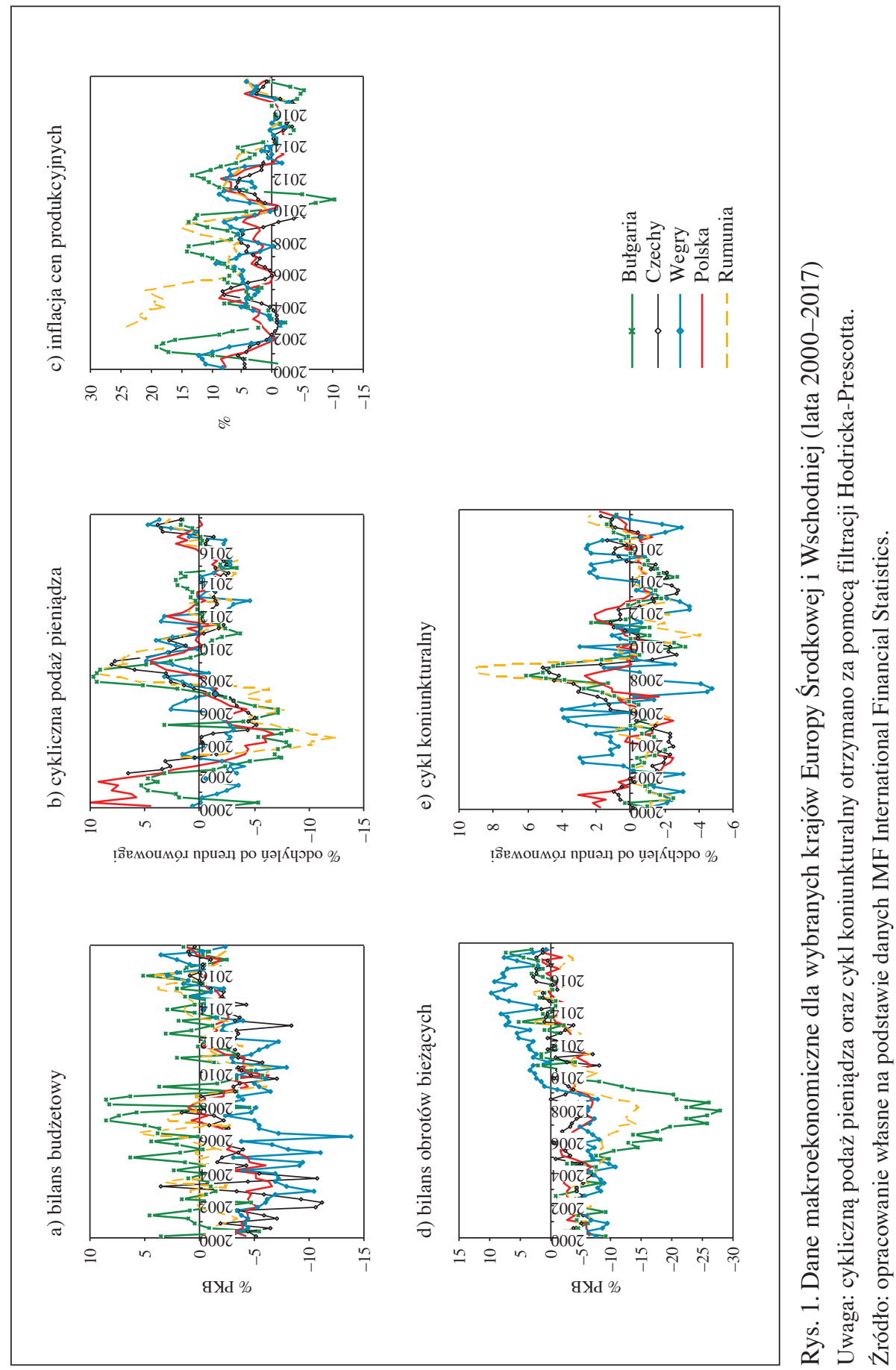


Z większości modeli makroekonomicznych wynika, że zwiększenie podaży pieniądza powoduje przejściowy wzrost dochodu (jeżeli w ogóle występuje), pogorszenie bilansu obrotów bieżących oraz wzrost poziomu cen (co najmniej w długim okresie). Makroekonomiczne efekty stymulowania fiskalnego są podobne, chociaż różnią się amplitudą oraz wizerunkiem stymulowania dochodu w czasie. Standardowe przewidywania zyskują empiryczne potwierdzenie zarówno w przypadku podaży pieniądza (Canova i Menz 2011, Favara i Giordani 2009, Hafer, Haslag i Jones 2007), jak i polityki fiskalnej (Ilzetzki, Mendoza i Végh 2013). Nie jest jednak wykluczone, że zmiany podaży pieniądza nie wywierają żadnego wpływu na dochód, nawet w krótkim okresie (Uhlig 2005), a mają wręcz restrykcyjny wpływ w gospodarkach z ograniczeniami rynku finansowego (Rojas-Suarez 1992). Podobnie występowanie niekeynesowskich efektów polityki fiskalnej oznacza, że to cięcia budżetowe są czynnikiem zwiększenia dochodu (Alesina i Ardagna 2009).

Celem artykułu jest zbadanie wpływu bilansu budżetowego oraz podaży pieniądza na inflację cen produkcyjnych (PPI), bilans obrotów bieżących oraz lukę dochodu dla wybranych pięciu krajów EŚW. Do modelowania relacji między bilansem budżetowym i podażą pieniądza a wskaźnikami makroekonomicznymi wykorzystano strukturalny model autoregresyjny (SVAR), który pozwala przewidywać uzależnienie podaży pieniądza w bieżącym okresie od bilansu obrotów bieżących, przy jednoczesnym uwzględnieniu zależności tego wskaźnika równowagi zewnętrznej od cyklu koniunkturalnego.

\section{Przegląd literatury}

W większości współczesnych modeli makroekonomicznych podaży pieniądza, zgodnie z dominującym poglądem, że agregaty pieniężne nie powinny wpływać na kształt polityki monetarnej (Rudebusch i Svensson 1999), równowagę wewnętrzną (dochód) i zewnętrzną (bilans płatniczy) traktuje się jako nieistotne czynniki ${ }^{1}$. Stanowisko to trudno uznać za uzasadnione zarówno z powodu ortodoksji ilościowej teorii podaży pieniądza, efektu bilansowego czy ograniczeń płynności (liquidity constraints), jak i licznych dowodów empirycznych potwierdzających istotne oddziaływanie podaży pieniądza na sektor realny zarówno w krajach uprzemysłowionych, jak i w gospodarkach rozwijających się (Canova i Menz 2011).

\footnotetext{
${ }^{1}$ Obszerny przegląd rozmaitych zagadnień dotyczących szoków polityki fiskalnej i pieniężnej w warunkach otwartości gospodarek przedstawiła A. Domańska (2015, s. 93-116). Szczegółową analizę teoretycznych modeli polityki fiskalnej przeprowadziła w pracy monograficznej E. Rogalska (2016).
} 
Istotne oraz trwałe oddziaływanie podaży pieniądza na dochód stwierdzono np. w badaniach odnoszących się do Chin (Sun 2013). Wcześniejsze badania dotyczące krajów byłego Związku Radzieckiego nie są tak jednoznaczne, jeśli chodzi o ocenę realnych efektów polityki monetarnej (Starr 2005). W odniesieniu do krajów EŚW ustalono, że podaż pieniądza ma wpływ na inflację, ale odpowiednia relacja nie wydaje się zbyt mocna (Horváth, Komárek i Rozsypal 2011). Wcześniejsze badania wskazują na słabsze (ale podobne) efekty polityki monetarnej w krajach EŚW w porównaniu z krajami Europy Zachodniej (Anzuini i Levy 2007). W niektórych późniejszych badaniach wskazywano jednak, że inflacyjne efekty polityki monetarnej są nawet większe niż w krajach strefy euro, szczególnie w okresie dłuższym niż rok (Jarociński 2010).

Wydaje się, że makroekonomiczny wpływ podaży pieniądza jest zróżnicowany w poszczególnych krajach. Ustalono np., że szoki nominalne dominują jako czynnik inflacyjny w Polsce, a na Węgrzech ceny zależą głównie od efektów bilansu płatniczego. $Z$ drugiej strony zmiany podaży pieniądza wywierają wpływ na dochód w krótkim okresie na Węgrzech, w Polsce natomiast dominują szoki podażowe (Dibooglu i Kutan 2005). W późniejszych badaniach dotyczących Polski, przeprowadzonych z wykorzystaniem modeli autoregresji wektorowej stwierdzono, że zacieśnianie polityki monetarnej prowadzi do spadku aktywności gospodarczej oraz cen (Chmieliewski i in. 2017). Podobnie standardowe keynesowskie cechy polityki monetarnej odnotowano w Czechach (Borys, Horváth i Franta 2009) i Chorwacji (Ćorić, Šimović i Deskar-Škrbić 2015). Chociaż relacja między podażą pieniądza a cenami najprawdopodobniej słabnie przy obniżeniu stopy inflacji, agregaty pieniężne wciąż odgrywają istotną rolę w kształtowaniu inflacji, dotyczy to np. Argentyny (Basco, D’Amato i Caregnani 2009).

Wpływ podaży pieniądza na bilans obrotów bieżących (bilans handlowy) zależy od występowania dwóch asymetrycznych efektów: absorpcyjnego i substytucyjnego (expenditure switching). W odniesieniu do kilku krajów europejskich stwierdzono, że efekt substytucyjny jest mocniejszy, co sugeruje możliwość poprawy bilansu handlowego w przypadku ograniczenia podaży pieniądza (Kim 2001).

Większość badań dla krajów EŚW przemawia na korzyść standardowych keynesowskich cech polityki fiskalnej (Ambriŝko i in. 2013, Combes i in. 2016, Kabashi 2017, Mirdala 2009). Można w nich także znaleźć argumenty na poparcie hipotezy bliźniaczego deficytu, ponieważ deficyt budżetowy prowadzi do pogorszenia się bilansu obrotów bieżących (Bollano i Ibrahimaj 2015, Mirdala 2013). Należy odnotować, że wcześniejsze badania wskazują na występowanie tzw. niekeynesowskiej relacji między bilansem budżetowym a dochodem (Rzońca i Ciżkowicz 2005, Segura-Ubiergo, Simone i Gupta 2006). Ostatnio występowanie efektów niekeynesowskich polityki fiskalnej dla krajów EŚW potwierdzono, dokonując oszacowania danych panelowych (Redo 2017, s. 57-77, Rogalska 2016). 
Zgodnie z ustaleniami L. Rojas-Suarez (1992, s. 594-613), ekspansywne efekty nadwyżki budżetowej oraz ograniczenia podaży pieniądza mogą być wyjaśnione za pomocą modelu gospodarki zależnej z ograniczeniami na rynku finansowym.

\section{Model teoretyczny}

Jak można wywnioskować na podstawie przeglądu literatury przedmiotu, badania empiryczne wskazują na różnorodność funkcjonalnego wpływu narzędzi polityki fiskalnej i monetarnej. Sytuacja ta powoduje, że trudno znaleźć model teoretyczny przydatny do wyjaśnienia odmiennych skutków polityki ekonomicznej w bardzo podobnym środowisku makroekonomicznym, jakie tworzą kraje EŚW. W tym kontekście pewną przewagę ma wspomniany model gospodarki zależnej (Rojas-Suarez 1992, s. 594-613), który pozwala na uzyskanie odmiennych makroekonomicznych efektów bilansu budżetowego i podaży pieniądza w zależności od cech strukturalnych popytu i podaży oraz sposobu kształtowania oczekiwań co do kursu walutowego.

Zasadnicze relacje modelu gospodarki zależnej przedstawiają się następująco (Rojas-Suarez 1992, s. 594-613) ${ }^{2}$ :

$$
\begin{gathered}
\left(Q_{s}^{T}\right)_{t}=s_{0}+s_{1}\left(m_{t}-E_{t-1} p_{t}^{N}\right)+s_{2} \gamma E_{t-1}\left(e_{t}+p_{t}^{T}-p_{t}^{N}\right)+u_{t}, \\
\left(Q_{s}^{N}\right)_{t}=s_{0}+s_{1}\left(m_{t}-E_{t-1} p_{t}^{N}\right)-s_{2}(1-\gamma) E_{t-1}\left(e_{t}+p_{t}^{T}-p_{t}^{N}\right)+u_{t}, \\
\left(Q_{d}^{T}\right)_{t}=a_{0}-\beta E_{t}\left(e_{t+1}+p_{t+1}^{T}-p_{t+1}^{N}\right)+a_{1}\left(m_{t}-E_{t}\left(e_{t+1}+p_{t+1}^{T}\right)\right)+ \\
+a_{2}\left(E_{t} i_{t+1}-e_{t}-p_{t}^{T}\right)-a_{3}\left(r_{t}^{*}+E_{t} e_{t+1}-e_{t}-\left(E_{t} i_{t+1}-i_{t}\right)\right)+a_{4} g_{t}+\varepsilon_{t}, \\
\left(Q_{d}^{N}\right)_{t}=b_{0}+\beta E_{t}\left(e_{t+1}+p_{t+1}^{T}-p_{t+1}^{N}\right)+b_{1}\left(m_{t}-E_{t} p_{t+1}^{N}\right)+ \\
+b_{2}\left(E_{t} i_{t+1}-p_{t}^{N}\right)-b_{3}\left(r_{t}^{*}+E_{t} e_{t+1}-e_{t}-\left(E_{t} i_{t+1}-i_{t}\right)\right)+b_{4} g_{t}+\varepsilon_{t}, \\
m_{t}=y_{t}+p_{t}^{N}-l_{1}\left(r_{t}^{*}+E_{t} e_{t+1}-e_{t}\right), \\
R_{t}=\left(Q_{s}^{T}\right)_{t}-\left(Q_{d}^{T}\right)_{t}+\left(1-d_{1}\right)\left(e_{t}+p_{t}^{T}\right)+d_{1} R_{t-1},
\end{gathered}
$$

gdzie: $y_{t}$ - dochód (PKB), $\left(Q_{s}^{T}\right)_{t} \mathrm{i}\left(Q_{d}^{T}\right)_{t},\left(Q_{s}^{N}\right)_{t} \mathrm{i}\left(Q_{d}^{N}\right)_{t}, p_{t}^{T}$ i $p_{t}^{N}$ - odpowiednio podaż, popyt oraz ceny dóbr będących i niebędących przedmiotem wymiany w handlu międzynarodowym (tradable and nontradable goods), odpowiednio, $i_{t}$ - ogólny poziom cen, $m_{t}-$ podaż pieniądza, $g_{t}-$ deficyt budżetowy, $e_{t}-$ nominalny kurs walutowy, $r_{t}^{*}$ - poziom stopy procentowej za granicą, $R_{t}$ - rezerwy walutowe, $u_{t} \mathrm{i} \varepsilon_{t}$-podażowe i popytowe szoki stochastyczne. Wszystkie zmienne

\footnotetext{
${ }^{2}$ Przedstawiony model uzupełniono równaniem równowagi na rynku pieniężnym.
} 
wyrażone są za pomocą logarytmów, oprócz $g_{t}$ i $r_{t}^{*}$. Operatory $E_{t}$ i $E_{t-1}$ oznaczają oczekiwania, które są formułowane, odpowiednio, w okresach $t$ i $t-1$.

W równaniach (1) i (2) produkcja dóbr $Q^{T}$ i $Q^{N}$ zależy od oczekiwań co do podaży pieniądza w ujęciu realnym (efekt finansowy) i realnego kursu walutowego, a także czynnika stochastycznego $u_{t}$. Popyt na dobra będące przedmiotem wymiany w handlu międzynarodowym $Q^{T}$ rośnie w przypadku oczekiwań co do aprecjacji realnego kursu walutowego i zwiększenia podaży pieniądza w ujęciu realnym (efekt majątkowy), przyspieszenia inflacji oraz obniżki poziomu stopy procentowej (równanie (3)). Efekt majątkowy jest uzależniony od retrospektywnych oczekiwań co do cen dóbr niebędących przedmiotem wymiany w handlu międzynarodowym. Podobnie w równaniu (4) wyznaczono popyt na dobra niebędące przedmiotem wymiany w handlu międzynarodowym $Q^{N}$. Efekt substytucyjny $\beta$ odzwierciedla siłę wpływu oczekiwań co do cen względnych na strukturę popytu. Inflacja cen konsumenckich uwzględnia ceny dóbr $Q^{T}$ i $Q^{N}: i_{t}=\gamma p_{t}^{N}+(1-\gamma)\left(e_{t}+p_{t}^{T}\right)$. Uczestnicy rynku decydują o wielkości i strukturze popytu w okresie $t$ na podstawie oczekiwań dotyczących okresu $t+1$, biorąc pod uwagę oczekiwania co do wielkości produkcji sformułowane w poprzednim okresie $t-1$. W równaniu (5) popyt na pieniądz rośnie w przypadku zwiększenia dochodu i obniżenia nominalnej stopy procentowej.

Równanie (6) prezentuje zależność rezerw walutowych od popytu na dobra $Q^{T}$ i ich podaży w warunkach kursu sztywnego. W przypadku systemu kursu płynnego równowaga zewnętrzna przewiduje bilansowanie popytu na dobra będące przedmiotem wymiany w handlu międzynarodowym i ich podaży $Q^{T}:\left(Q_{s}^{T}\right)_{t}=\left(Q_{d}^{T}\right)_{t}$. Natomiast równowaga wewnętrzna dotyczy popytu na dobra niebędące przedmiotem wymiany w handlu międzynarodowym i ich podaży $Q^{N}:\left(Q_{s}^{N}\right)_{t}=\left(Q_{d}^{N}\right)_{t}$.

Model (równania (1)-(6)) przewiduje, że w warunkach kursu płynnego deficyt budżetowy jest restrykcyjny przy większym udziale dóbr będących przedmiotem wymiany w handlu międzynarodowym w wydatkach budżetowych $\left(a_{4}>b_{4}\right)$ oraz większym udziale kursu walutowego w kształtowaniu inflacji; w innym wypadku można oczekiwać, że nastąpi zwiększenie dochodu. Przy kursie sztywnym deficyt budżetowy powoduje zmniejszenie dochodu wskutek wzrostu cen dóbr niebędących przedmiotem wymiany w handlu międzynarodowym. Podobna sytuacja powstaje w przypadku oczekiwań co do kursu walutowego sformułowanych na podstawie podaży pieniądza $\left(E_{t} e_{t+1}=m_{t}\right)$, co może występować w warunkach de iure kursu sztywnego, jak i polityki stabilizacji kursu walutowego przez interwencje banku centralnego przy zadeklarowanym kursie płynnym. Oddziaływanie deficytu budżetowego na bilans obrotów bieżących zależy od zmian popytu na dobra będące przedmiotem wymiany w handlu międzynarodowym i ich podaży, przy uwzględnieniu cen dóbr niebędących przedmiotem wymiany. Jeżeli wystę- 
puje większy wzrost cen w sektorze $Q^{N}$, co skutkuje zmniejszeniem podaży dóbr będących przedmiotem wymiany w handlu międzynarodowym, a efekt substytucyjny w zakresie popytu na dobra $Q^{T}$ i $Q^{N}$ nie jest wystarczająco mocny, standardowa relacja budżetu i bilansu obrotów bieżących - według wzorców deficytu bliźniaczego - może nie wystąpić.

Przewidywane zwiększenie podaży pieniądza jest neutralne względem dochodu przy kursie płynnym, jak to wynika z neoklasycznych modeli z racjonalnymi oczekiwaniami, ale w przypadku oczekiwań co do kursu walutowego sformułowanych na podstawie podaży pieniądza powstają warunki do uzyskania efektu restrykcyjnego, przy jednoczesnym przyśpieszeniu inflacji. W przypadku kursu płynnego podaż pieniądza nie powinna mieć wpływu na bilans obrotów bieżących wskutek deprecjacji kursu walutowego, ale słaby efekt substytucyjny w zależności od wielkości efektów finansowego i majątkowego w sektorze $Q^{T}$ powoduje, że wpływ taki jest możliwy. Podobnie jest w sytuacji, kiedy występują oczekiwania co do kursu walutowego sformułowane na podstawie podaży pieniądza. W przypadku kursu sztywnego większa podaż pieniądza powoduje zwiększenie dochodu oraz cen dóbr niebędących przedmiotem wymiany w handlu międzynarodowym, co powinno skutkować pogorszeniem się bilansu obrotów bieżących oraz zmniejszeniem poziomu rezerw walutowych.

\section{Dane i metodologia statystyczna}

Do oszacowań empirycznych wykorzystano dane kwartalne z lat 2000Q12017Q3, pochodzące z bazy danych IMF International Financial Statistics (IFS). Jak pokazano na rys. 1, komponenty cykliczne PKB (indeks PKB $2010=100$ ), $y c_{t}$, oraz podaży pieniądza, mierzone jako odchylenie agregatu pieniężnego M2 od jego trendu (\%), $m c_{t}$, otrzymano z wykorzystaniem filtracji Hodricka-Prescotta. Wskaźniki pierwotnego bilansu budżetowego, $b d_{t}$, oraz bilansu obrotów bieżących, $c a_{t}$, podano w \% PKB, a inflacji cen produkcyjnych (PPI), $p_{t}$, w \%. Saldo budżetowe jest najczęściej stosowane $\mathrm{w}$ analizach empirycznych jako dobre przybliżenie wpływu polityki fiskalnej na zagregowany popyt, przede wszystkim w krajach postsocjalistycznych, chociaż jest ono w znacznym stopniu uzależnione od wahań koniunktury (Mackiewicz i Krajewski 2008). Warto zwrócić uwagę, że budżety krajów przechodzących transformację i nadrabiających zaległości rozwojowe zazwyczaj uważa się za mniej wrażliwe na zmiany koniunktury niż budżety krajów OECD, co uzasadnia wykorzystanie salda pierwotnego (pierwotne saldo strukturalne jest często wykorzystywane w literaturze przedmiotu dotyczącej dostosowań fiskalnych w krajach rozwiniętych (Rogalska 2016, s. 121)). 
Wszystkie rzędy czasowe oprócz PPI oczyszczono z sezonowości z wykorzystaniem procedury Census X12. Test ADF (augmented Dickey-Fuller test) wskazuje na stacjonarność niemal wszystkich rzędów czasowych (tabela 1). Pewne wątpliwości budzi zmienna $c a_{t}$ dla Bułgarii i Rumunii, ale w obu przypadkach stacjonarność zostaje potwierdzona za pomocą alternatywnych testów Phillipsa-Perrona oraz KPSS.

Jeśli jako wyjściowy model VAR przyjmiemy $A_{0} X_{t}=A(L) X_{t-1}+B \varepsilon_{t}$, odpowiedni strukturalny model wektorowej autoregresji możemy zapisać w postaci zredukowanej:

$$
X_{t}=A_{0}^{-1} A(L) X_{t-1}+A_{0}^{-1} B \varepsilon_{t}=C(L) X_{t-1}+u_{t},
$$

gdzie: $X_{t}$ - wektor o wymiarach $n \times 1$ zmiennych endogenicznych, $A(L)$ - kowariancyjna macierz wielomianu opóźnień, $A_{0}$ - macierz zawierająca wyrazy wolne, które przedstawiają relacje w bieżącym okresie między zmiennymi endogenicznymi, $C(L)$ - macierz przedstawiająca relacje między opóźnionymi zmiennymi endogenicznymi, $L$ - operator opóźnień, $\varepsilon_{t}-n$-wymiarowy wektor składników losowych, które mają rozkład normalny, nie są skorelowane i są względem siebie ortogonalne, $u_{t}-n$-wymiarowy wektor reszt VAR o wartości oczekiwanej 0 , które nie są skorelowane seryjnie, ale mogą być skorelowane w bieżącym okresie.

Tabela 1. Test ADF dla krajów EŚW

\begin{tabular}{|l|c|c|c|c|c|}
\hline \multicolumn{1}{|c|}{ Kraj } & $b d_{t}$ & $m c_{t}$ & $p_{t}$ & $c a_{t}$ & $y c_{t}$ \\
\hline Bułgaria & $-5,76^{* * *}$ & $-2,25^{* * *}$ & $-2,76^{* * *}$ & $-1,32$ & $-4,88^{* * *}$ \\
\hline Czechy & $-2,83^{* * *}$ & $-2,48^{* *}$ & $-4,82^{* * *}$ & $-1,88^{*}$ & $-3,58^{* * *}$ \\
\hline Polska & $-4,06^{* * *}$ & $-3,54^{* * *}$ & $-2,15^{* *}$ & $-1,85^{*}$ & $-3,55^{* * *}$ \\
\hline Węgry & $-5,93^{* * *}$ & $-3,89^{* * *}$ & $-3,41^{* * *}$ & $-1,79^{*}$ & $-5,74^{* * *}$ \\
\hline Rumunia & $-2,75^{* * *}$ & $-1,61^{*}$ & $-6,50^{* * *}$ & $-1,27$ & $-3,14^{* * *}$ \\
\hline
\end{tabular}

Uwaga: hipotezę zerową o pierwiastku jednostkowym można odrzucić: ${ }^{* * *}$ na poziomie istotności statystycznej $0,01,{ }^{* *}$ na poziomie $0,05,{ }^{*}$ na poziomie 0,10 .

Źródło: opracowanie własne.

Przyjmując, że reszty VAR w postaci zredukowanej są powiązane ze strukturalnymi szokami w postaci $A_{0} u_{t}=B \varepsilon_{t}$, specyfikację modelu SVAR możemy przedstawić następująco:

$$
\begin{gathered}
b d=u_{1}, \\
m c=a_{1} b d+a_{2} c a+u_{2}, \\
p=b_{1} b d+b_{2} m c+u_{3}, \\
c a=c_{1} y c+c_{2} p+u_{4}, \\
y c=d_{1} b d+d_{2} m c+d_{3} p+d_{4} c a+u_{5} .
\end{gathered}
$$


Wszystkie zmienne w równaniach (8)-(12) to reszty modelu VAR w bieżącym okresie. Ponieważ wprowadzenie zmian w polityce fiskalnej w odpowiedzi na sytuację makroekonomiczna zazwyczaj wymaga okresu dłuższego niż trzy miesiące, przyjmuje się, że w bieżącym okresie bilans budżetowy nie zależy od pozostałych zmiennych endogenicznych (równanie (8)). Zmiany w cyklicznej podaży pieniądza dokonują się pod wpływem zarówno bilansu budżetowego, jak i bilansu obrotów bieżących, co odzwierciedla warunki sterylizacji efektów monetarnych bilansu płatniczego (równanie (9)). Inflacja cen produkcyjnych zależy zarówno od podaży pieniądza, jak i bilansu budżetowego (równanie (10)). Bilans obrotów bieżących zależy od obu czynników - cenowego (PPI) i dochodu (cykl koniunkturalny) (równanie (11)). Oznacza to, że polityka fiskalna i monetarna oddziałują na bilans obrotów bieżących przez mechanizmy dochodu i cen. Cykl koniunkturalny w bieżącym okresie zależy od wszystkich zmiennych endogenicznych (równanie (12)).

Spośród zmiennych egzogenicznych w modelach SVAR uwzględniono zmienne stopy procentowej LIBOR oraz cyklu koniunkturalnego krajów strefy euro (\%). Zmienną zero-jedynkową wykorzystano do kontroli efektów kryzysu światowego z lat 2008-2009. Uwzględniając średnią ustaloną na podstawie kilku kryteriów informacyjnych (AIC, FPE, HQ, SC, HQ), dla każdego z krajów wybrano opóźnienia o 2 kwartały $^{3}$. W każdym z oszacowanych modeli SVAR potwierdzono stacjonarność reszt za pomocą testów Dickeya-Fullera (ADF) i Phillipsa-Perrona (PP), co świadczy o poprawnych własnościach statystycznych.

\section{Wyniki}

Analizę reakcji pozostałych zmiennych endogenicznych na jednostkowe zmiany bilansu budżetowego oraz podaży pieniądza zaprezentowano na rys. 2 i 3 . Na osi poziomej przedstawiono kwartalne okresy po wystąpieniu szoku zmiennej endogenicznej, natomiast na osi pionowej oszacowania funkcji reakcji oraz poziomy ufności dla badanego wskaźnika.

Wystąpienie impulsu w postaci nadwyżki budżetowej prowadzi do zwiększenia podaży pieniądza w trzech z pięciu krajów (rys. 2). W Rumunii jest odwrotnie, a w Bułgarii podaż pieniądza nie wykazuje reakcji na szok fiskalny. Przedziały ufności wskazują, że skutek impulsu jest istotny dla Polski, Rumunii oraz Węgier.

3 Testy Schwarza i Hannana-Quina wskazują na opóźnienie o zaledwie jeden kwartał dla wszystkich badanych krajów, według pozostałych kryteriów opóźnienia wynoszą 2 (Czechy), 3 (Wegry) oraz 4 kwartały (Bułgaria, Polska, Rumunia). Wybór opóźnień o 2 kwartały wydaje się rozwiązaniem kompromisowym, które odpowiada wykorzystaniu danych w postaci odchyleń od trendu równowagi (intuicyjnie wskazuje to na niższy rząd modelu VAR/SVAR). 
Zwiększenie podaży pieniądza powoduje pogorszenie bilansu budżetowego w Polsce i Bułgarii (w obu przypadkach wpływ impulsu wygasa w stosunkowo wolnym tempie). Natomiast w Czechach i na Węgrzech występuje krótkookresowa poprawa bilansu budżetowego. W Rumunii polityka fiskalna nie zależy od podaży pieniądza.

Reakcja PPI na nadwyżkę budżetową jest podobna w przypadku Polski, Czech i Bułgarii; na jej podstawie przewidywać można obniżenie inflacji cen producenta z opóźnieniem czasowym. Na Węgrzech dochodzi do natychmiastowego spadku inflacji, ale efekt ten jest krótkotrwały. Oddziaływania nadwyżki budżetowej na PPI nie odnotowano dla Rumunii. Podaż pieniądza nie wywiera wpływu na PPI zarówno w Polsce, jak i Bułgarii pomimo odmiennych systemów kursu walutowego. Na Węgrzech efekt inflacyjny występuje w pierwszych dwóch kwartałach, a w Czechach - po dwóch latach od szoku monetarnego. Jedynie w Rumunii ceny produkcji przemysłowej maleją, co może świadczyć o znaczącym efekcie finansowym w sektorze $Q^{N}$. Większa podaż pieniądza powoduje zatem wzrost produkcji dóbr i usług niebędących przedmiotem wymiany w handlu międzynarodowym powyżej przyrostu popytu w sektorze $Q^{N}$ (efekt majątkowy).

Na podstawie analizy dekompozycji reszt można stwierdzić, że w Rumunii impuls monetarny stopniowo zwiększa swój wpływ na zmiany PPI do $23 \%$ (tabela 2). W przypadku Polski wpływ nie występuje, a w pozostałych krajach udział $m c$ w zmianach PPI wynosi 3-8\%. W Polsce odnotowano największy (na poziomie 12\%) udział bilansu budżetowego w zmianach PPP, co nie dowodzi mocnego oddziaływaniu polityki fiskalnej na ceny produkcji przemysłowej. W Polsce i Czechach dynamika PPI istotnie zależy od zmian bilansu obrotów bieżących; udział $c a_{t} \mathrm{w}$ dekompozycji reszt $p_{t}$ stanowi odpowiednio $30 \%$ i $15 \%$. W żadnym z krajów nie zidentyfikowano zależności PPI od cyklu koniunkturalnego.

Relację według schematu deficytu bliźniaczego - budżetu i bilansu obrotów bieżących - odnotowano w Polsce, Czechach i na Węgrzech, ale jej przebieg w czasie jest w tych krajach odmienny. Po impulsie fiskalnym na Węgrzech występuje permanentna poprawa bilansu obrotów bieżących, w Czechach taka korekta $c a$ jest obserwowana zaledwie przez rok. W Polsce początkowo wpływu się nie obserwuje, ale po roku następuje poprawa bilansu obrotów bieżących (maksymalną poprawę $c a_{t}$ osiąga się po 8 kwartałach), reakcja $c a_{t}$ na impuls fiskalny jest jednak dużo słabsza niż na Węgrzech i w Czechach. W przypadku Rumunii relacja między $b d_{t}$ i $c a_{t}$ nie występuje, a w przypadku Bułgarii reakcja jest nietypowa. Poprawa bilansu budżetowego natychmiast powoduje pogorszenie się bilansu obrotów bieżących, co można wyjaśnić niekorzystnymi efektami podażowymi w sektorze $Q^{T}$. Takie przypuszczenie potwierdza reakcja ca na impuls monetarny. Podobna relacja występuje w Rumunii. W Polsce i na Węgrzech wpływ podaży pieniądza na $c a$ nie występuje, co świadczy o równowadze efektów finansowego 

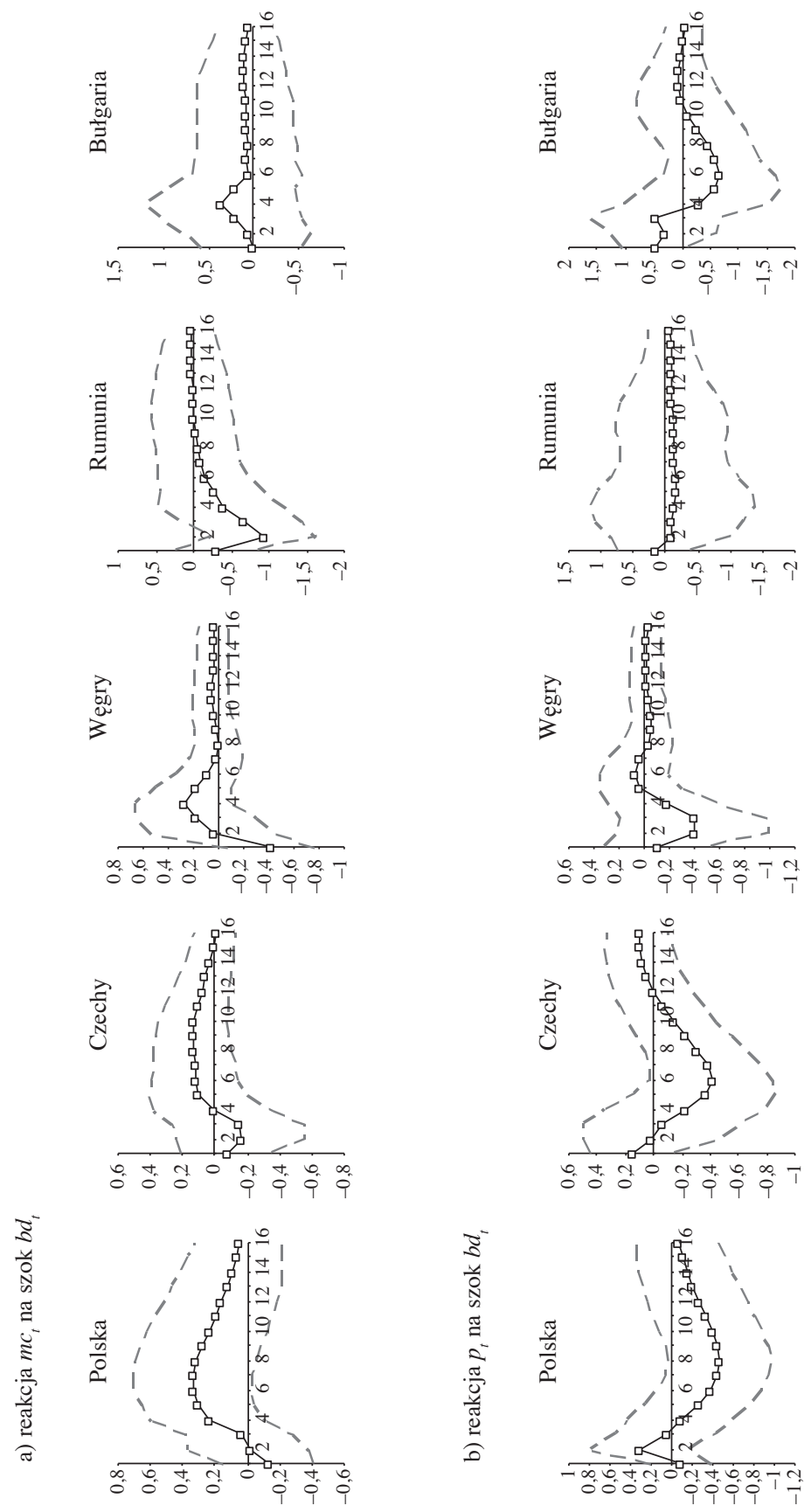

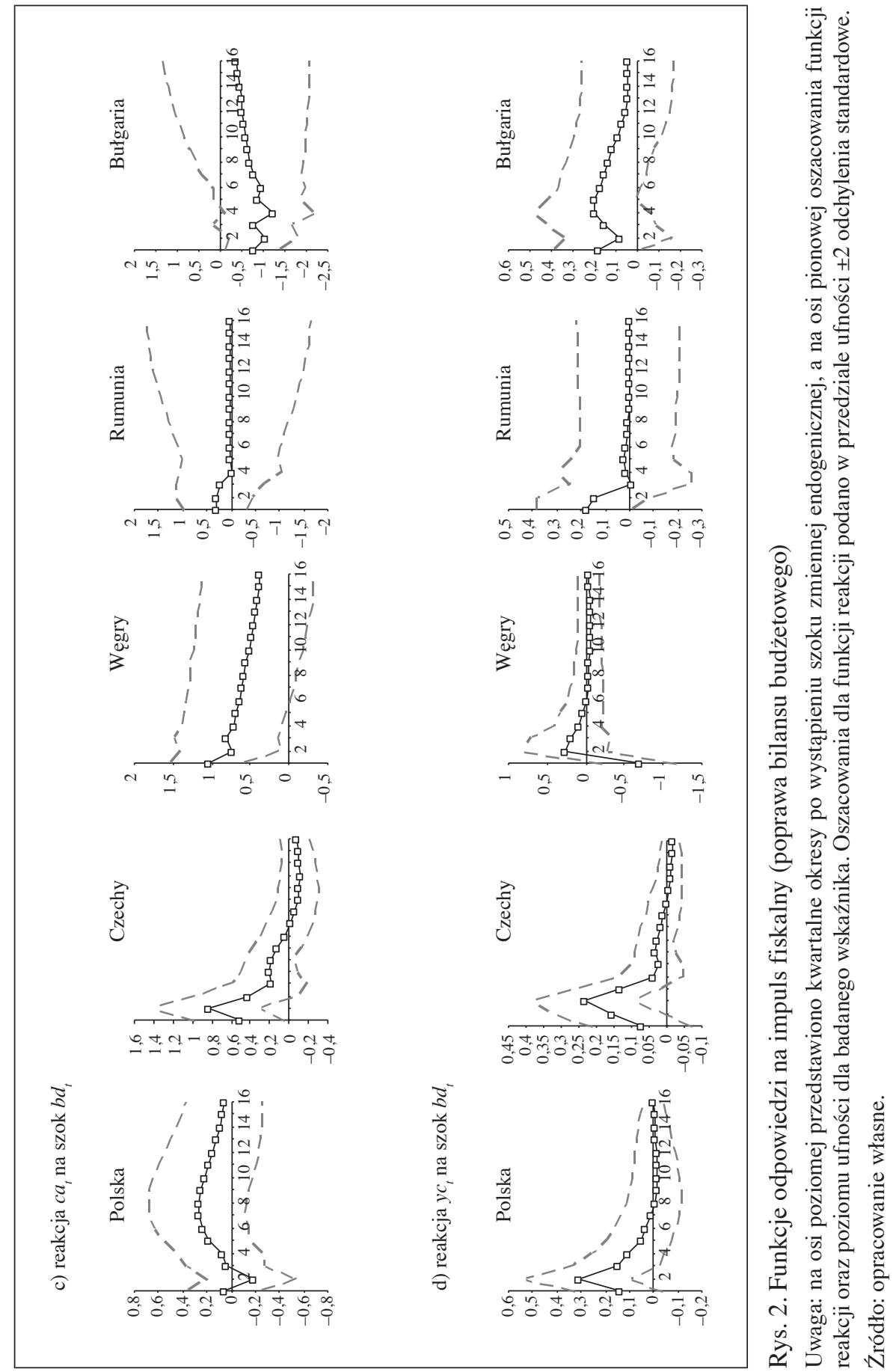

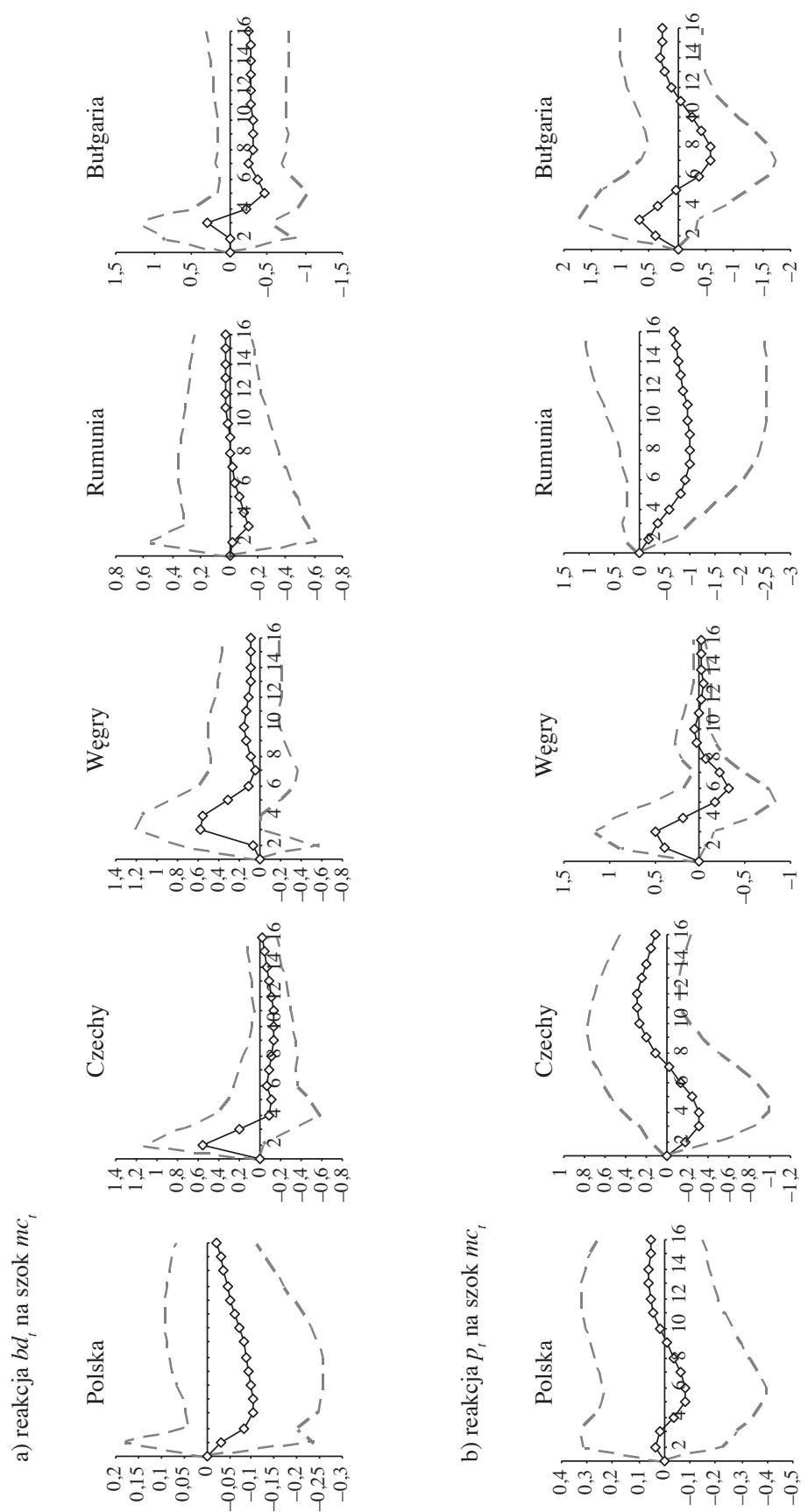

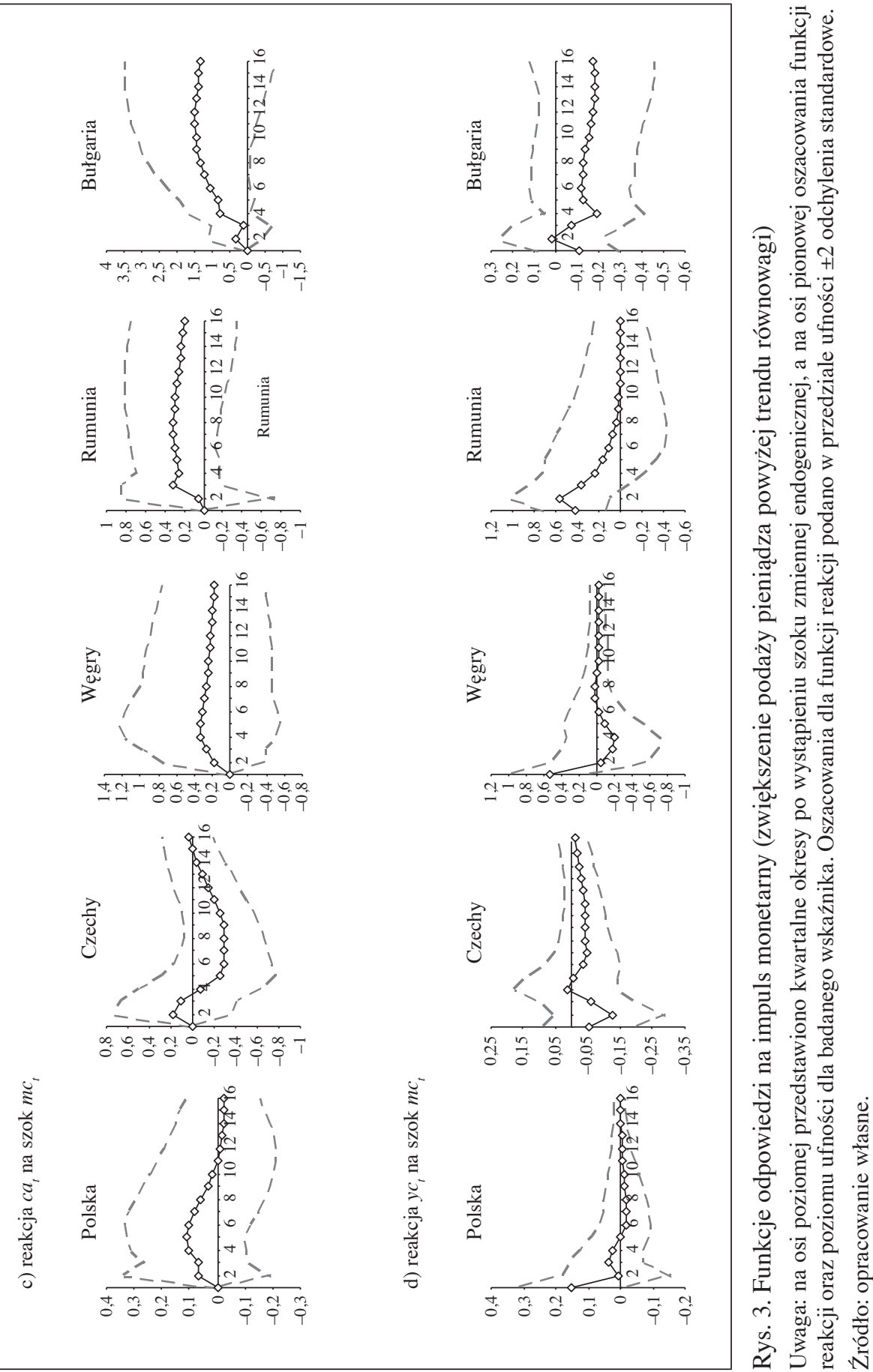
i majątkowego w sektorze $Q^{T}$. Jedynie w Czechach po roku od szoku monetarnego odnotowuje się pogorszenie bilansu obrotów bieżących, co wskazuje na mocny efekt majątkowy w sektorze $Q^{T}$. Wykorzystując inną argumentacę (Kim 2001), pogorszenie się bilansu obrotów bieżących wskutek zwiększenia podaży pieniądza w Czechach świadczy o mocniejszym efekcie absorpcyjnym, a przeciwna relacja w przypadku Bulgarii i Rumunii o przewadze efektu substytucyjnego.

Tabela 2. Dekompozycja reszt modeli SVAR dla poszczególnych krajów

\begin{tabular}{|c|c|c|c|c|c|c|c|c|c|}
\hline \multirow{3}{*}{ Kraj } & \multirow{3}{*}{$\begin{array}{c}\text { Zmienna } \\
\text { zależna }\end{array}$} & \multicolumn{8}{|c|}{ Reakcja na szok } \\
\hline & & \multicolumn{4}{|c|}{$b d_{t}$} & \multicolumn{4}{|c|}{$m c_{t}$} \\
\hline & & 4 & 8 & 12 & 16 & 4 & 8 & 12 & 16 \\
\hline Bułgaria & \multirow[t]{5}{*}{$p_{t}$} & 3 & 7 & 7 & 7 & 3 & 5 & 6 & 7 \\
\hline Czechy & & 1 & 7 & 7 & 7 & 3 & 4 & 6 & 7 \\
\hline Polska & & 2 & 8 & 11 & 12 & 0 & 0 & 0 & 0 \\
\hline Rumunia & & 1 & 1 & 1 & 1 & 4 & 16 & 22 & 23 \\
\hline Węgry & & 5 & 5 & 5 & 5 & 6 & 8 & 8 & 8 \\
\hline Bułgaria & \multirow[t]{5}{*}{$c a_{t}$} & 21 & 18 & 14 & 12 & 4 & 16 & 26 & 31 \\
\hline Czechy & & 21 & 20 & 19 & 19 & 1 & 6 & 9 & 9 \\
\hline Polska & & 1 & 6 & 8 & 9 & 1 & 1 & 1 & 1 \\
\hline Rumunia & & 3 & 3 & 3 & 3 & 2 & 6 & 9 & 10 \\
\hline Węgry & & 24 & 24 & 24 & 24 & 2 & 3 & 4 & 4 \\
\hline Bułgaria & \multirow{5}{*}{$y c_{t}$} & 9 & 15 & 14 & 13 & 5 & 8 & 14 & 17 \\
\hline Czechy & & 22 & 21 & 21 & 21 & 5 & 5 & 6 & 7 \\
\hline Polska & & 16 & 18 & 18 & 18 & 3 & 3 & 3 & 3 \\
\hline Rumunia & & 1 & 1 & 1 & 1 & 18 & 18 & 18 & 18 \\
\hline Węgry & & 11 & 11 & 11 & 11 & 6 & 6 & 6 & 6 \\
\hline
\end{tabular}

Uwaga: przedstawiono udział zmiennych bilansu budżetowego $(b d)$ oraz cyklicznej podaży pieniądza $\left(m c_{t}\right)$ w dekompozycji reszt innych zmiennych endogenicznych, tzn. inflacji cen producentów $\left(p_{t}\right)$, bilansu obrotów bieżących $\left(c a_{t}\right)$ oraz cyklu koniunkturalnego $\left(y c_{t}\right)$, z horyzontem $4,8,12$ i 16 kwartałów.

Źródło: opracowanie własne.

Dekompozycja reszt wskazuje na znaczny wpływ polityki fiskalnej i monetarnej na zmiany bilansu obrotów bieżących w Bułgarii. Wpływ bilansu budżetowego na bilans obrotów bieżących jest największy w Czechach i na Węgrzech. W przypadku Polski i Rumunii udział $b d_{t}$ w zmianach $c a_{t}$ osiąga odpowiednio maksymalnie $9 \%$ i $3 \%$. W Czechach i Rumunii wpływ $m c_{t}$ na $c a_{t}$ wynosi maksymalnie $10 \%$, a w Polsce i na Węgrzech jest marginalny. Spośród innych znaczących czynników oddziałujących na zmiany bilansu obrotów bieżących wskazać należy udział PPI, który wynosi $10 \%$ dla Czech i 15\% dla Polski. W żadnym z krajów nie stwierdzono 
istotnej zależności bilansu obrotów bieżących od cyklu koniunkturalnego. Ogólnie rzecz biorąc, oznacza to, że zmiany ca zależą głównie od czynników zewnętrznych.

Występowanie krótkookresowych efektów niekeynesowskich polityki fiskalnej zauważa się w Polsce, Czechach i Rumunii. W Bułgarii korzystny impuls fiskalny jest bardziej trwały w czasie. Jednocześnie korzystny impuls monetarny odnotowano tylko w Rumunii. W przypadku Bułgarii otrzymane rezultaty wskazują na możliwość wpływu restrykcyjnego. W modelu gospodarki zależnej taka możliwość występuje w przypadku oczekiwań co do kursu walutowego sformułowanych na podstawie podaży pieniądza, co istotnie zmienia przewidywania teoretyczne dla kursu sztywnego. Impuls fiskalny wyraźnie dominuje w zmianach cyklicznych PKB Czech i Polski, w Rumunii zaobserwowano natomiast, że większy wpływ ma impuls monetarny. W Bułgarii udział obu szoków w dekompozycji reszt yc właściwie się nie różni, ale nie wydaje się zbyt mocny. Jeszcze słabszy wpływ odnotowano na Węgrzech. Jednocześnie w Bułgarii cykl koniunkturalny istotnie zależy od zmian PPI (20\%) i bilansu obrotów bieżących (20\%). Podobnie PPI wywiera znaczny wpływ na zmiany cykliczne PKB w Polsce (18\%) i Rumunii (20\%). Większy wpływ $c a_{t}$ na zmiany $y c_{t}$ otrzymano również dla Polski i Czech (7\%).

\section{Podsumowanie}

Efekty polityki fiskalnej i monetarnej w pięciu badanych krajach EŚW (Bułgaria, Czechy, Polska, Rumunia i Węgry) są zróżnicowane, ale można z pewnością stwierdzić, że obawy dotyczące niekorzystnego oddziaływania polityki obniżenia deficytu budżetowego na cykliczną dynamikę PKB są bezzasadne. Co więcej, w krótkim okresie można spodziewać się zwiększenia dochodu (z wyjątkiem Węgier), spowolnienia inflacji cen produkcyjnych (Polska, Czechy, Bułgaria) i poprawy bilansu obrotów bieżących (Polska, Czechy, Węgry). Ogólnie potwierdzono wyniki poprzednich badań dotyczących występowania niekeynesowskich efektów polityki fiskalnej (Rzońca i Ciżkowicz 2005, Segura-Ubiergo, Simone i Gupta 2006, Redo 2017, s. 57-77, Rogalska 2016). Efekty polityki monetarnej są bardzo zróżnicowane, co nie pozwala stwierdzić jednoznacznie występowania podobieństwa między krajami EŚW a krajami Europy Zachodniej, jak to czyniono w niektórych badaniach (np. Anzuini i Levy 2007). Otrzymane rezultaty przemawiają na korzyść modelu gospodarki zależnej, który wyjaśnia różnorodność efektów polityki monetarnej występowaniem efektów sektoralnych w popycie na dobra będące i niebędące przedmiotem wymiany w handlu międzynarodowym i podaży tych dóbr. W przypadku zwiększenia podaży pieniądza można spodziewać się przyspieszenia inflacji cen produkcyjnych w krótkim (Bułgaria, Węgry) i długim okresie (Czechy), nie jest jednak wykluczona deflacja 
PPI (Rumunia). Poprawa bilansu obrotów bieżących występuje w Bułgarii i Rumunii, ale w Czechach odnotowuje się jego pogorszenie. Asymetryczne oddziaływanie na cykl koniunkturalny stwierdzono na podstawie oszacowań dla Rumunii oraz Bułgarii, a w przypadku pozostałych krajów podaż pieniądza okazała się neutralna względem dochodu.

Występowanie deficytu bliźniaczego potwierdzono dla Polski, Czech i Węgier, co odpowiada rezultatom większości badań empirycznych. W przypadku Bułgarii dostrzega się jednak asymeryczną relację między bilansem budżetowym a bilansem obrotów bieżących. Odmienne rezultaty co do relacji między podażą pieniądza a bilansem obrotów bieżących mogą być wyjaśnione występowaniem zarówno efektów sektoralnych popytu i podaży, jak i dwóch innych efektów - absorpcyjnego i substytucyjnego (Kim 2001). W większości krajów nadwyżka budżetowa powoduje zwiększenie podaży pieniądza (Polska, Czechy, Węgry), chociaż trzeba zaznaczyć, że przeciwna relacja występuje w Rumunii. Poluzowanie polityki monetarnej (zwiększenie podaży pieniądza powyżej trendu) prowadzi do pogorszenia bilansu budżetowego w Polsce i Bułgarii, ale do krótkotrwałej poprawy tego wskaźnika w Czechach i na Węgrzech.

\section{Literatura}

Alesina A., Ardagna S. (2009), Large Changes in Fiscal Policy: Taxes versus Spending, NBER Working Paper, no. 15438, National Bureau of Economic Research Cambridge, Mass.

Ambriŝko R., Babecky J., Rysanek J., Valenta V. (2015), Assessing the Impact of Fiscal Measures on the Czech Economy, „Economic Modelling”, vol. 44 (C), https://doi. org/10.1016/j.econmod.2014.07.021.

Anzuini A., Levy A. (2007), Monetary Policy Shocks in the New EU Members: a VAR Approach, ,Applied Economics”, vol. 39, nr 9, https://doi.org/10.1080/ 00036840600592866.

Basco E., D'Amato L., Caregnani L. (2009), Understanding the Money-prices Relationship under Low and High Inflation Regimes: Argentina 1977-2006, ,Journal of International Money and Finance", vol. 28, nr 7, https://doi.org/10.1016/j.jimonfin.2009.06.008.

Bollano J., Ibrahimaj D. (2015), Current Account Determinants in Central Eastern European Countries, GIIDS Working Paper, HEIDWP0022-2015, Graduate Institute of International and Development Studies, Geneva.

Borys M.M., Horváth R., Franta M. (2009), The Effects of Monetary Policy in the Czech Republic: An Empirical Study, „Empirica”, vol. 36, nr 4.

Canova F., Menz T. (2011), Does Money Matter in Shaping Domestic Business Cycles? An International Investigation, „Journal of Money Credit \& Banking”, vol. 43, $\mathrm{nr} 4$, https://doi.org/10.1111/j.1538-4616.2011.00388.x.

Chmieliewski T., Kapuściński M., Kocięcki A., Łyziak T., Przystupa J., Stanisławska E., Wróbel E. (2017), Mechanizm transmisji polityki pieniężnej w Polsce. Stan wiedzy w 2017 roku, Materiały i Studia nr 330, Narodowy Bank Polski, Warszawa. 
Combes J.L., Minea A., Mustea L., Yogo T. (2016), Output Effects of Fiscal Stimulus in Central and Eastern European Countries, ,Post-Communist Economies”, vol. 28, nr 1, https://doi.org/10.1080/14631377.2015.1124559.

Ćorić T., Šimović H., Deskar-Škrbić M. (2015), Monetary and Fiscal Policy Mix in a Small Open Economy: The Case of Croatia, „Economic Research-Ekonomska Istraživanja”, vol. 28, nr 1, https://doi.org/10.1080/1331677X.2015.1059073.

Dibooglu S., Kutan, A. (2005), Sources of Inflation and Output Movements in Poland and Hungary: Policy Implications for Accession to the Economic and Monetary Union, „Journal of Macroeconomics”, vol. 27, nr 2, https://doi.org/10.1016/j.jmacro.2003.07.003.

Domańska A. (2015), Szoki polityki fiskalnej i monetarnej jako przedmiot badań makroekonomii gospodarki otwartej, Kwartalnik Kolegium Ekonomiczno-Społecznego „Studia i Prace”, nr 1.

Favara G., Giordani P. (2009), Reconsidering the Role of Money for Output, Prices and Interest Rates, ,Journal of Monetary Economics”, vol. 56, nr 3, https://doi.org/10.1016/ j.jmoneco.2009.01.002.

Hafer R., Haslag J., Jones G. (2007), On Money and Ooutput: Is Money Redundant?, „Journal of Monetary Economics", vol. 54, nr 3, https://doi.org/10.1016/j.jmoneco.2005.06.004.

Horváth R., Komárek L., Rozsypal F. (2011), Does Money Help Predict Inflation? An Empirical Assessment for Central Europe, ,Economic Systems”, vol. 35, nr 3, https://doi.org/10.1016/j.ecosys.2011.03.001.

Ilzetzki E., Mendoza E., Végh C. (2013), How Big (Small?) Are Fiscal Multipliers?, ,Journal of Monetary Economics", vol. 60, nr 2, https://doi.org/10.1016/j.jmoneco.2012.10.011.

Jarocinski M. (2010), Responses to Monetary Policy Shocks in the East and the West of Europe: A Comparison, „Journal of Applied Econometrics”, vol. 25, nr 5, https://doi. org/10.1002/jae.1082.

Kabashi R. (2017), Macroeconomic Effects of Fiscal Policy in the European Union, with Particular Reference to Transition Countries, „Public Sector Economics”, vol. 41, nr 1, https://doi.org/10.3326/pse.41.1.7.

Kim S. (2001), Effects of Monetary Policy Shocks on the Trade Balance in Small Open European Countries, ,Economics Letters”, vol. 71, nr 2, https://doi.org/10.1016/S0165-1765(01)00364-0.

Mackiewicz M., Krajewski P. (2008), Skala i efektywność antycyklicznej polityki fiskalnej $w$ kontekście wstapienia Polski do strefy euro, Uniwersytet Łódzki, Łódź.

Mirdala R. (2013), Fiscal Imbalances and Current Account Adjustments in the European Transition Economies, „Journal of Applied Economic Sciences”, vol. 8, nr 3.

Redo M. (2017), Niekeynesowska zależność pomiędzy tempem wzrostu gospodarczego a wielkościq dochodów $i$ wydatków publicznych (w relacji do PKB) w latach 20012015 w 11 państwach Europy Środkowo-Wschodniej należqcych do Unii Europejskiej, Czasopismo Komitetu Nauk o Finansach PAN „Finanse”, nr 1(10).

Rogalska E. (2016), Dostosowania fskalne w krajach Europy Środkowo-Wschodniej, Polskie Towarzystwo Ekonomiczne, Toruń.

Rojas-Suarez L. (1992), Limited Capital Markets and the Real Effects of Monetary Stabilization Policies under Alternative Exchange Rate Regimes, ,Journal of International Money and Finance", vol. 11, nr 6.

Rudebusch G., Svensson L. (1999), Policy Rules and Inflation Targeting (w:) Monetary Policy Rules, ed. J. Taylor, University of Chicago Press, Chicago.

Rzońca A., Ciżkowicz P. (2005), Non-Keynesian Effects of Fiscal Contraction in New Member States, ECB Working Paper, no 519, European Central Bank, Frankfurt. 
Segura-Ubiergo A., Simone A., Gupta S. (2006), New Evidence on Fiscal Adjustment and Growth in Transition Economies, IMF Working Paper, 06/244.

Starr M. (2005), Does Money Matter in the CIS? Effects of Monetary Policy on Output and Prices, ,Journal of Comparative Economics”, vol. 33, nr 3, https://doi.org/10.1016/ j.jce.2005.05.006.

Sun R. (2013), Does Monetary Policy Matter in China? A Narrative Approach, „China Economic Review", vol. 26, nr 1, https://doi.org/10.1016/j.chieco.2013.03.003.

Uhlig H. (2005), What Are the Effects of Monetary Policy on Output? Results from an Agnostic Identification Procedure, ,Journal of Monetary Economics”, vol. 52, nr 2, https://doi.org/10.1016/j.jmoneco.2004.05.007.

Windberger T., Crespo Cuaresma J., Walde J. (2010), Dirty Floating and Monetary Independence in Central and Eastern Europe - the Role of Structural Breaks, University of Innsbruck Working Papers in Economics and Statistics, nr 2012-21.

Zezza G. (2012), The Impact of Fiscal Austerity in the Eurozone, „Review of Keynesian Economics", Inaugural Issue.

\section{Macroeconomic Effects of Fiscal and Monetary Policies in the Central and East European Countries}

(Abstract)

Objective: The aim of this paper is to study the effects of budget balance and money supply on producer price inflation (PPI), the current account balance and the output gap for five Central and East European (CEE) countries (Bulgaria, the Czech Republic, Hungary, Poland and Romania).

Research Design \& Methods: Based on the quarterly data over the 2000-2017 period, macroeconomic effects of the budget balance and money supply are estimated with the Structural Vector Autoregressive (SVAR) model, which anticipates reliance of the money supply upon the current account balance on impact, with a simultaneous dependence of the latter upon the business cycle.

Findings: A budget surplus did not cause any output losses in any of the five CEE countries. For three of the countries (Bulgaria, the Czech Republic, Poland), a budget surplus is associated with decelerating producer price inflation and improvement in the current account balance (the Czech Republic, Hungary, Poland). A budget surplus is likely to bring about an increase in the money supply. Expansionary monetary policy is a factor behind either worsening of the budget balance (Bulgaria, Poland), or a short-lived improvement in it (the Czech Republic, Hungary). Macroeconomic effects of the money supply tend to be heterogeneous, supporting both demand-side and supply-side transmission mechanisms. Implications / Recommendations: Our results favour conservative fiscal and monetary policies in all five of the CEE countries, particularly in the Czech Republic and Poland. Contribution: The scientific contribution of the article is that it justifies the use of the dependent economy model, with output disaggregated into tradable and nontradable sectors, for analysis of economic policy in the CEE countries.

Keywords: budget balance, money supply, current account, business cycle, producer price inflation. 